\title{
Perennial Ryegrass and Tall Fescue Reseeding Intervals after Aminocyclopyrachlor Application
}

\author{
John B. Workman ${ }^{1}$, Patrick E. McCullough ${ }^{2,4}$, and F. Clint Waltz \\ Department of Crop and Soil Sciences, University of Georgia, 1109 Experiment \\ Street, Griffin, GA 30223-1797
}

James T. Brosnan²
Department of Plant Sciences, University of Tennessee, Knoxville, TN 37996

Gerald M. Henry ${ }^{2}$

Department of Plant and Soil Science, Texas Tech University, Lubbock, TX 79409-2122

Additional index words. establishment, turf, herbicide, weeds

\begin{abstract}
Turfgrass managers applying aminocyclopyrachlor for annual and perennial broadleaf weed control in cool-season turfgrasses may want to reseed into treated areas. Field experiments were conducted in Georgia), Tennessee, and Texas to investigate perennial ryegrass (Lolium perenne L.) and tall fescue (Festuca arundinacea Schreb.) reseeding intervals after aminocyclopyrachlor applications. Perennial ryegrass and tall fescue establishment were similar to the non-treated control after treatments of aminocyclopyrachlor and 2,4-dichlorophenoxyacetic acid (2,4-D) + dicamba + methylchlorophenoxypropionic acid (MCPP) at 0,2 , 4, or 6 weeks before seeding. Results demonstrate that no reseeding interval is required after aminocyclopyrachlor treatment. Perennial ryegrass and tall fescue can be safely seeded immediately after aminocyclopyrachlor treatment at 39, 79, and $158 \mathrm{~g} / \mathrm{a} . \mathrm{i} . / \mathrm{ha}$.
\end{abstract}

Synthetic auxins are popular herbicides for selective, postemergence broadleaf weed control in turfgrass management (Struckmeyer, 1951; Watson, 1950). Herbicides in this class of chemistry control susceptible weeds by disrupting hormonal balance leading to increased cell wall plasticity, nucleic acid metabolism, and uncontrolled growth in meristimatic regions (Sterling and Hall, 1997). A new synthetic auxin, aminocyclopyrachlor, was registered in 2010 for annual and perennial broadleaf weed control in turfgrass (Anonymous, 2010).

Aminocyclopyrachlor is the first pyrimidine carboxylic acid herbicide with structural similarities to pyridines (Bukum et al., 2010). This herbicide has both foliar and soil activity and is more effective at lower rates than 2,4$\mathrm{D}$ and other auxin herbicides (Flessner et al., 2011; Turner et al., 2009). Aminocyclopyrachlor has efficacy on many broadleaf weed species including wild carrot (Daucus carota L.) Canada thistle [Cirsium arvense (L.) Scop.], Japanese knotweed (Fallopia japonica Houtt.), catsear dandelion (Hypochoeris radicata L.), and plantains (Plantago spp.)

\footnotetext{
Received for publication 27 June 2011. Accepted for publication 1 Oct. 2011.

${ }^{1}$ Graduate Assistant.

${ }^{2}$ Assistant Professor

${ }^{3}$ Associate Professor.

${ }^{4}$ To whom reprint requests should be addressed; e-mail pmccull@uga.edu.
}

(Anonymous, 2010; Bukum et al., 2010; Curtis et al., 2009; Rudenko, 2009).

Aminocyclopyachlor has promising implications for controlling problematic broadleaf weeds in turfgrass, but turfgrass managers may want to re-establish cool-season grasses from seed after applications. Application timing and rate of postemergence herbicides from various herbicide families have been reported to inhibit establishment of cool- and warm-season turfgrasses from seed. Prepackage products that include auxin herbicides 2,4-D, dicamba, and MCPP are recommended to be applied 3 to 4 weeks before seed is sown or after two to three mowing events (Anonymous, 2004). Quinclorac, a highly selective auxin herbicide, has shown to be safe when applied at seeding of annual bluegrass (Poa annua L.), tall fescue (Festuca arundinacea Schreb.), perennial ryegrass (Lolium perenne L.), and fine fescue for pre-weed control during establishment (Anonymous, 1998; Enache and Ilnicki, 1991). Reicher et al. (1999) found that quinclorac at 0.84 $\mathrm{kg} \cdot \mathrm{ha}^{-1}$ did not injure kentucky bluegrass (Poa pratensis L.) or perennial ryegrass when applied at seeding. These experiments did note that quinclorac applied at seeding delayed the cover of kentucky bluegrass up to 16 weeks (Reicher et al., 1999). Bispyribac sodium applied 1 week before seeding (WBS) reduced creeping bentgrass (Agrostis stolonifera L.) and kentucky bluegrass by $30 \%$ and $42 \%$ compared with the non-treated control, respectively. However, these grasses were safely established when bispyribac sodium was applied 2 WBS (Lycan and Hart, 2006). Sulfosulfuron at 13 to $26 \mathrm{~g} / \mathrm{a}$.i./ha applied the day of seeding or 1 WBS reduced creeping bentgrass and kentucky bluegrass establishment compared with the non-treated control (McCullough and Nutt, 2010; Willis et al., 2007). Amicarbazone applied at $0.4 \mathrm{~kg} \cdot \mathrm{ha}^{-1}$ has the potential to reduce perennial ryegrass and tall fescue cover when applied the day of seeding. However, researchers noted that perennial ryegrass and tall fescue establishment appears uninhibited when amicarbazone at the same rate is applied 2, 4, or 6 WBS (McCullough et al., 2011). Common bermudagrass [Cynodon dactylon (L.) Pers.] seedlings have shown significant injury and reduced establishment in response to rimsulfuron, simazine, and trifloxysulfuron applied 1 to 2 WBS (McCullough and Nutt, 2010; Willis et al., 2007). McCalla et al. (2004) reported that 'Princess 77 ' bermudagrass seedlings exhibited $30 \%$ or less injury after applications of diclofop, metsulfuron, 2,4-D, dicamba, monosodium acid methanearsonate (MSMA), clopyralid, and quinclorac applied 1,2 , and 4 weeks after emergence. McElroy et al. (2005) noted that prepackaged mixtures of herbicides containing 2,4-D, mecoprop, dicamba, clopyralid, or triclopyr should be used with caution when applied at seeding or before stolon development with warm-season grasses. The researchers found that low and high rates of 2,4-D + mecoprop + dicamba and 2,4-D + clopyralid + dicamba reduced bermudagrass cover of the cultivars Yukon, Riviera, and Princess $721 \mathrm{~d}$ after initial treatment when compared with the nontreated control (McElroy et al., 2005).

Turfgrass managers may need to reseed desirable turfgrasses like perennial ryegrass and tall fescue after broadleaf weeds have been controlled by aminocyclopyrachlor or other postemergence herbicides. Thus, reseeding intervals may be critical for new herbicides introduced for postemergence broadleaf weed control in turf management regimes. Data describing reseeding intervals after aminocyclopyrachlor treatments are limited. In the transition zone and cool humid region of the United States, tall fescue and perennial ryegrass are widely used for residential lawns, golf courses, and commercial properties. The objective of this research was to determine reseeding intervals for perennial ryegrass and tall fescue after aminocyclopyachlor applications.

\section{Materials and Methods}

Experiments were conducted in Griffin, GA, Knoxville, TN, and Lubbock, TX, from Aug. 2010 to Mar. 2011. Experiments at all three locations were initiated on mature, irrigated tall fescue that was mowed weekly with a rotary mower at a $6.4-\mathrm{cm}$ height. Clippings were returned. Soil in Georgia was a Cecil sandy loam (fine, kaolinitic, thermic Typic Kanhapludults) with $2.5 \%$ organic matter and a $\mathrm{pH}$ of 5.8. Soil in Tennessee was a Sequatchie loam (fine-loamy, siliceous, 
semiactive, thermic humic Hapludult) with $2.1 \%$ organic matter and a $\mathrm{pH}$ of $6.2 \%$. Soil in Texas was a Brownfield sand clay loam soil (loamy, mixed, superactive, thermic Arenic Aridic Paleustalfs) with $1.6 \%$ organic matter and a $\mathrm{pH}$ of 8.0

Experimental design. Separate studies were conducted to determine reseeding intervals for perennial ryegrass and tall fescue. The experimental design for each was a randomized complete block with four replications. Four herbicide treatments were applied at four application timings before seeding in addition to a non-treated control. Aminocyclopyrachlor (Imprelis 2SL; DuPont, Wilmington, DE) was applied at 39,78 , or $158 \mathrm{~g} / \mathrm{a} . \mathrm{i} . / \mathrm{ha}$ and 2, 4-D + dicamba + MCPP (Trimec Classic 2.72 SL; PBI Gordon Corp., Kansas City, MO) was applied at $1100+300+100$ g/a.i./ ha, respectively. Herbicide treatments were applied 0, 2, 4, or 6 WBS. Application dates in Georgia, Tennessee, and Texas are presented in Table 1. Aminocyclopyrachlor rates were selected from previous research evaluating broadcast applications of aminocyclopyrachlor for selective broadleaf weed control (Flessner et al., 2011). The 2, 4-D + dicamba + MCPP rates were selected from label recommendations (Anonymous, 2004).

Treatments were applied to $1 \times 3.6-\mathrm{m}$ plots in Georgia and $1.5 \times 3.6-\mathrm{m}$ plots in Texas and Tennessee. In Georgia, treatments were applied by making two passes in opposite directions with a single nozzle (Teejet 9504E flat fan spray nozzle; Spraying Systems Co., Roswell, GA) $\mathrm{CO}_{2}$-pressured sprayer calibrated to deliver $375 \mathrm{~L} \cdot \mathrm{ha}^{-1}$. In Tennesse and Texas, treatments were applied by making one pass per plot with a four nozzle (Teejet 8002 flat fan spray nozzle; Spraying Systems Co.) $\mathrm{CO}_{2}$-pressured sprayer calibrated to deliver $280 \mathrm{~L} \cdot \mathrm{ha}^{-1}$.

Turfgrass seeding and maintenance. Seven days before seeding, each experimental site received a broadcast application of glyphosate (Roundup Pro. Monsanto Company, St. Louis, $\mathrm{MO})$ at $3.3 \mathrm{~kg} / \mathrm{a}$.i./ha to kill existing vegetation and facilitate visual assessment of turfgrass seedling cover. On the day of seeding, the field was mowed to $3.8 \mathrm{~cm}$ with a rotary mower, debris was removed, and the seedbed received two additional passes with a vertical mower set to a depth of $\approx 1.3 \mathrm{~cm}$. Perennial ryegrass (Manhattan IV perennial ryegrass; Pure Seed Testing, Inc., Hubbard, OR) and tall fescue (Titan tall fescue; Seed Research of Oregon, Inc., Corvallis, OR) were seeded separately and perpendicular to herbicide treatments over half of all plots at $390 \mathrm{~kg} \cdot \mathrm{ha}^{-1}$ with a drop spreader. Herbicide treatments scheduled for the day of seeding were applied immediately after seeding each grass species. After seeding, tall fescue and perennial ryegrass were irrigated daily to promote germination and applied as needed to prevent turf wilt after germination. A $10 \mathrm{~N}-10 \mathrm{P}_{2} \mathrm{O}_{5}-10 \mathrm{~K}_{2} \mathrm{O}$ ) granular

Table 1. Dates of treatment application and seeding in field experiments in Griffin, GA, Knoxville, TN, and Lubbock, TX, in 2010.

\begin{tabular}{lccrr}
\hline Application & Week before seeding & Georgia & Tennessee & Texas \\
\hline Treatments & 6 & 17 Aug. & 16 Aug. & 24 Aug. \\
& 4 & 1 Sept. & 30 Aug. & 7 Sept. \\
& 2 & 14 Sept. & 13 Sept. & 21 Sept. \\
Glyphosate & 0 & 29 Sept. & 28 Sept. & 5 Oct. \\
Seeding & 1 & 21 Sept. & 20 Sept. & 28 Sept. \\
\hline
\end{tabular}

Table 2. 'Manhattan IV' perennial ryegrass cover after herbicide treatments at four application timings before seeding in field experiments conducted in 2010-2011. ${ }^{\mathrm{z}}$

\begin{tabular}{|c|c|c|c|c|c|c|}
\hline \multirow[b]{3}{*}{ Treatment $^{\mathrm{x}}$} & \multirow[b]{3}{*}{ Rate (g/a.i./ha) } & \multicolumn{5}{|c|}{ Perennial ryegrass cover (WAS) $)^{y}$} \\
\hline & & 2 & 4 & 8 & 12 & 20 \\
\hline & & \multicolumn{5}{|c|}{ 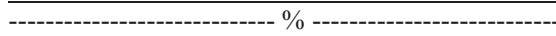 } \\
\hline Aminocyclopyrachlor & 39 & 54 & 88 & 96 & 99 & 99 \\
\hline & 79 & 54 & 88 & 95 & 98 & 99 \\
\hline & 158 & 54 & 88 & 95 & 99 & 99 \\
\hline 2,4-D + dicamba + MCPP & $1100+100+300$ & 54 & 89 & 96 & 99 & 99 \\
\hline
\end{tabular}

Application timing (WBS) ${ }^{\mathrm{v}}$

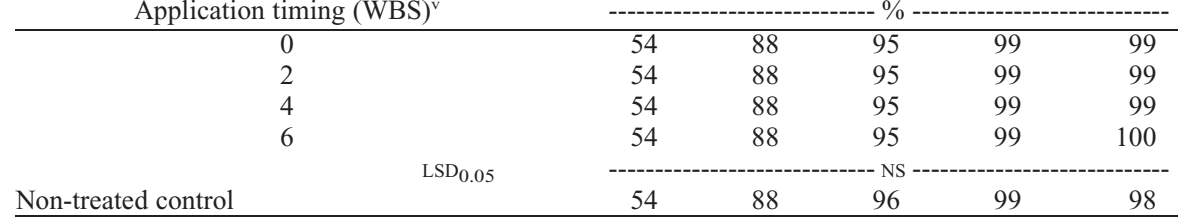

${ }^{2}$ Means are combined for experiments conducted in, Griffin, GA, Knoxville, TN, and Lubbock, TX.

${ }^{\mathrm{y}} \mathrm{WAS}=$ weeks after seeding.

xInitial applications were applied on 17 Aug., 16 Aug., and 24 Aug. in Georgia, Tennessee, and Texas, respectively. Seeding dates were 29 Sept., 28 Sept., and 5 Oct. in Georgia, Tennessee, and Texas, respectively.

${ }^{\mathrm{w}} \mathrm{NS}=$ nonsignificant at $0.05 P$ level.

${ }^{\mathrm{V}} \mathrm{WBS}=$ weeks before seeding

$\mathrm{MCPP}=$ methylchlorophenoxypropionic acid; LSD = least significant difference. fertilizer was applied at $48 \mathrm{~kg} \mathrm{~N} / \mathrm{ha} \approx 4$ weeks after seeding (WAS) at each location.

Measurements and statistical analysis. Perennial ryegrass and tall fescue cover were assessed visually, because Yelverton et al. (2009) reported that visual ratings of herbicide responses in turf were highly correlated to those measured using the line intersect method or digital image analysis. Turf cover was evaluated for each species $2,4,8,12$, and 20 WAS on a percent scale where 0 equaled no turf cover and 100 equaled complete turf cover.

Data were subjected to analysis of variance with main effects and all possible interactions tested using the appropriate expected mean square values as described by McIntosh (1983). Data were pooled from all three locations because location-by-treatment interactions were not detected for tall fescue or perennial ryegrass cover. Means were separated with Fisher's protected least significant difference test at the $0.05 P$ level.

\section{Results}

Perennial ryegrass study. A treatmentby-application timing interaction was not detected on any date for perennial ryegrass cover. Perennial ryegrass cover after aminocyclopyrachlor and 2,4-D + dicamaba + MCPP treatments was similar and not reduced from the non-treated control on any date regardless of application timing (Table 2 ). At 4, 8, and 12 WAS, perennial ryegrass had $88 \%, 95 \%$, and $99 \%$ cover, respectively, for all herbicides applied $0,2,4$, or 6 WBS At $20 \mathrm{WAS}$, no significant differences in perennial ryegrass cover were detected among application timing or herbicide treatments.

Tall fescue study. A treatment-by-application timing interaction was not detected on any date for tall fescue cover. Tall fescue cover after aminocyclopyrachlor and 2,4-D + dicamba + MCPP treatments was similar and was not reduced from the non-treated control on any date regardless of application timing (Table 3 ). At 4, 8, and 12 WAS, tall fescue had $77 \%$, $94 \%$, and $96 \%$ cover, respectively, for all herbicides applied at any of the timings. At 20 WAS, no significant differences in tall fescue cover were detected among application timings or herbicide treatments.

\section{Discussion}

Herbicide options are limited for turfgrass managers who are looking to control problematic weeds during establishment of coolseason grasses. Herbicides commonly used in established cool-season turfgrasses for PRE weed control such as dithiopyr, oryzalin, oxadiazon, pendimethalin, and prodiamine can injure immature and newly seeded coolseason turfgrass potentially leading to total failure of turfgrass establishment (Fermanian and Haley, 1994; Johnson and Murphy, 1991; Landschoot et al., 1993). Herbicides commonly used for post-weed control including 2,4-D, dicamba, MCPP, MSMA, or triclopyr 
Table 3. 'Titan II' tall fescue cover after herbicide treatments at four application timings before seeding in field experiments conducted in $2010-2011 .^{z}$

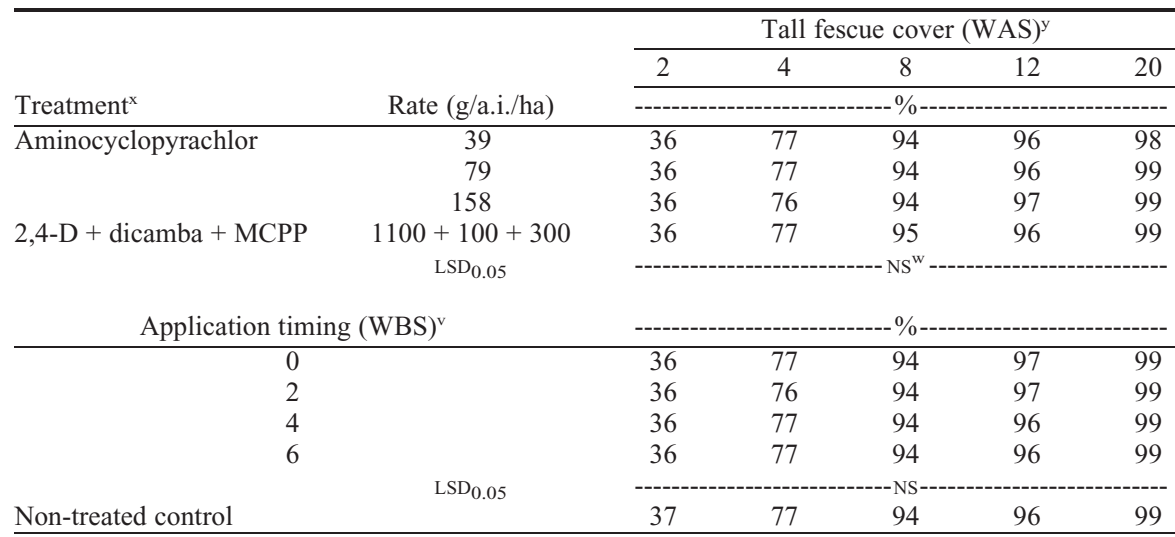

${ }^{\mathrm{z}}$ Means are combined for experiments conducted in Griffin, GA, Knoxville, TN, and Lubbock, TX.

${ }^{y} \mathrm{WAS}=$ weeks after seeding.

${ }^{\mathrm{x}}$ Initial applications were applied on 17 Aug., 16 Aug., and 24 Aug. in Georgia, Tennessee, and Texas, respectively. Seeding dates were 29 Sept., 28 Sept., and 5 Oct. in Georgia, Tennessee, and Texas, respectively.

${ }^{\mathrm{w}_{\mathrm{NS}}}=$ nonsignificant at $0.05 P$ level.

${ }^{\mathrm{N}} \mathrm{WBS}=$ weeks before seeding.

$\mathrm{MCPP}=$ methylchlorophenoxypropionic acid; $\mathrm{LSD}=$ least significant difference.

are recommended for use after seedlings have begun tillering or after mowing three to four times (Askew and Hipkins, 2005).

Results from this study demonstrate that perennial ryegrass and tall fescue can be safely treated with aminocyclopyrachlor applied at 39,79 , and $158 \mathrm{~g} \cdot \mathrm{ha}^{-1}$ immediately after seeding. Perennial ryegrass and tall fescue establishment appears uninhibited from aminocyclopyrachlor application; thus, no reseeding interval is required. Practitioners could selectively control broadleaf populations with aminocyclopyrachlor in the fall and safely reseed perennial ryegrass or tall fescue immediately after application. These results are comparable to similar studies that have shown certain herbicides including isoxaflutole, mesotrione, and quinclorac to be safe when applied during establishment of cool-season turfgrass (Askew et al., 2004; Willis et al., 2006). Further research should investigate application rates and intervals for use of aminocyclopyrachlor after turfgrass seedling emergence in perennial ryegrass and tall fescue stands as well as reseeding intervals with aminocyclopyrachlor application on warm-season turfgrass seed and vegetative material.

\section{Literature Cited}

Anonymous. 1998. Drive 75 DF herbicide label. EPA Reg. No. 7969-130. BASF Corporation, Research Triangle Park, NC.
Anonymous. 2004. Trimec Classic 2.72 SL herbicide label. PBI Gordon Corp., Kansas City, MO.

Anonymous. 2010. Imprelis herbicide label. DuPont, Newark, DE.

Askew, S.D., J.B. Beam, and W.L. Barker. 2004. Chemical options for selective control or suppression of bermudagrass in creeping bentgrass, kentucky bluegrass, and perennial ryegrass. Weed Sci. Soc. 57:101.

Askew, S.D. and P.L. Hipkins. 2005. Pest management guide for home grounds and animals-lawn weeds section. Virginia Cooperative Extension, Blacksburg, VA. p. 144-153.

Bukum, B., R.B. Bradley, S.J. Nissen, P. Westra, D.L. Shaner, and G. Brunk. 2010. Absorption and translocation of aminocyclopyrachlor and aminocyclopyrachlor-Methyl ester in Canada thistle (Cirsium arvense). Weed Sci. 58:96-102.

Curtis, D.W., B.J. Hinds-Cook, J. Barbara, B.D. Brewster, D. Bill, A.G. Hulting, and C.A. Mallory-Smith. 2009. Tolerance of perennial ryegrass and tall fescue grown for seed to aminocyclopyrachlor (DPXKJM-44). Western Weed Sci. Soc. 62:70-71.

Enache, A.E. and R.D. Ilnicki. 1991. Bas 514 and dithiopyr for weed control in cool-season turfgrasses. Weed Technol. 5:616-621.

Fermanian, T.W. and J.E. Haley. 1994. Application of prodiamine to immature turfs. Weed Technol. 8:617-620.

Flessner, M.L., R.R. Dute, and J.S. McElroy. 2011. Anatomical response of St. Augustinegrass to aminocyclopyrachlor treatment. Weed Sci. 59: 263-269.

Johnson, B.J. and T.R. Murphy. 1991. Response to fall-seeded tall fescue (Festuca Arundinacea) to spring-applied herbicides. Weed Technol. 5:304-309.

Landschoot, P.J., T.L. Watschke, and B.F. Hoyland. 1993. Influence of preemergence and postemergence herbicides on rooting of turfgrasses. Weed Technol. 7:123-126.

Lycan, D.W. and S.E. Hart. 2006. Cool-season turfgrass reseeding intervals for bispyribacsodium. Weed Technol. 20:526-529.

McCalla, J.H., Jr., M.D. Richardson, D.E. Karcher, and J.W. Boyd. 2004. Tolerance of seedling bermudagrass to postemergence herbicides. Crop Sci. 44:1330-1336.

McCullough, P.E., J.T. Brosnan, and G.K. Breeden. 2011. Tall fescue and perennial ryegrass reseeding intervals for amicarbazone. HortScience 46: 648-650.

McCullough, P.E. and W. Nutt. 2010. Bermudagrass reseeding intervals for rimsulfuron, simazine, and sulfosulfuron. HortScience 45:693-695.

McElroy, J.S., G.K. Breeden, F.H. Yelverton, T.W Gannon, S.D. Askew, and J.F. Derr. 2005. Response of four improved seeded bermudagrass cultivars to postemergence herbicides during seeded establishment. Weed Technol. 19:979-985.

McIntosh, M.S. 1983. Analysis of combined experiments. Agron. J. 75:153-155.

Reicher, Z.J., D.V. Weisenberger, and C.S. Throssell. 1999. Turf safety and Effectiveness of dithiopyr and quinclorac for large crabgrass (Digitaria sanguinalis) control in spring-seeded turf. Weed Technol. 13:253-256.

Rudenko, M. 2009. Integrating restoration and ecologically based weed management practices for invasive knotweed control. MS thesis, Oregon State University. p. 24-30.

Sterling, T. and J. Hall. 1997. Mechanism of action of natural auxins and the auxinic herbicides, p. 111-141. In: Roe, M., J. Burton, and R. Kuhr (eds.). Herbicide activity: Toxicology, biochemistry, and molecular biology. IOS Press, The Netherlands.

Struckmeyer, B. 1951. Comparative effects of growth substances on stem anatomy, p. 167174. Plant growth substances. Univ. Wisconsin Press, Madison, WI.

Turner, R., J. Claus, E. Hidalgo, M. Holliday, and G. Armel. 2009. Technical introduction of the new DuPont vegetation management herbicide aminocyclopyrachlor. Proc. South. Weed Sci. Soc. 62:405.

Watson, D. 1950. Anatomical modification of velvet bent grass (Agrostis canina L.) caused by soil treatment with 2,4-dichlorophenoxyacetic acid. Amer. J. Bot. 37:424-431.

Willis, J.B., J.B. Beam, W.L. Barker, and S.D Askew. 2006. Weed control options in springseeded tall fescue (Festuca arundinacea). Weed Technology 20:1040-1046.

Willis, J.B., D.B. Ricker, and S.D. Askew. 2007. Sulfonylurea herbicides applied during early establishment of seeded bermudagrass. Weed Technol. 21:1035-1038.

Yelverton, F.H., J.A. Hoyle, T.W. Gannon, and L.S. Warren. 2009. Plant counts, digital image analysis, and visual ratings for estimating weed control in turf: Are they correlated? Proc. South Weed Sci. Soc. 62:399. 